\title{
Investigating the role of different industries on relationship between working capital management and Tobin's Q
}

\author{
Mohammad Khodaei Valahzaghard ${ }^{a^{*}}$, Ali Saeedi ${ }^{a}$ and Nasrollah Moradpur ${ }^{b}$
}

\begin{abstract}
${ }^{a}$ Assist. Prof. \& Faculty Member, Department of Accounting, School of Management and Human Sciences, Tehran North Branch, Islamic Azad University (IAU), Tehran, Iran

${ }^{b}$ M.Sc. Student, Department of Accounting, School of Management and Human Sciences, Tehran North Branch, Islamic Azad University (IAU), Tehran, Iran

\section{H R O N I C L E}

Article history:

Received May 12, 2013

Received in revised format

12 September 2013

Accepted 6 October 2013

Available online

October 162013

Keywords:

Tobin's $Q$

Working capital management

A B S T R A C T

This paper presents an empirical investigation to study the effect of industry type on relationship between Tobin's Q and working capital management among selected firms from Tehran Stock Exchange. The proposed study gathers the necessary financial information from 219 different firms over the period 2001-2011 and categorizes them based on different sectors. There are five independent variables including current ratio, the ratio of current assets to total assets, debt ratio, the ratio of current liabilities to total assets and total cash. Using a linear regression by considering type of industry as dummy variable, the study detects that there was a positive and meaningful relationship between working capital and Tobin-Q in various industries.
\end{abstract}

Aggressive Investment Policy

Aggressive Financing Policy

\section{Introduction}

Working capital plays essential role on financial management and there are many studies to find how this could increase profitability of an organization (Filbeck \& Krueger, 2005). Deloof (2003) investigated the relationship between working capital management and corporate profitablity for a sample of 1,009 large Belgian non-financial companies over the period 1992-1996. The author computed trade credit policy and inventory policy by number of days' accounts receivable, accounts payable and inventories, and applied the cash conversion cycle as a comprehensice measure of working capital management. They reported that managers could increase corporate profitablity by reducing the number of days' accounts receivable and inventories. Eljelly (2004) investigated the relationship between profitability and liquidity measured by current ratio and cash gap on a sample of

*Corresponding author. Tel: +98-912-3443139

E-mail address: m_khodaei@iau-tnb.ac.ir (M. Khodaei Valahzaghard)

(C) 2013 Growing Science Ltd. All rights reserved. doi: $10.5267 / \mathrm{j} . \mathrm{ms} 1.2013 .10 .018$ 
3032

joint stock companies in Saudi Arabia. Using correlation and regression analysis the study reported substantial negative relationship between the firm's profitability and its liquidity level, as measured by current ratio. This relationship was more evident in firms with high current ratios and longer cash conversion cycles. At the industry level, nevertheless, the study detected that the cash conversion cycle or the cash gap was of more importance as a measure of liquidity than current ratio that influences profitability. The size variable was also detected to have significant impact on profitability at the industry level. Samiloglu and Demirgunes (2008) investigated the effect of working capital management on firm profitability by looking into some evidence from Turkey. García-Teruel and Martínez-Solano (2007) provided some empirical evidence on the effects of working capital management on the profitability of a sample of small and medium-sized Spanish firms. Gardner et al. (1986) investigated working capital policy and operating risk. Padachi (2006) studied trends in working capital management and its impact on firms' performance.

\section{The proposed study}

This paper presents an empirical investigation to study the effect of industry type on relationship between Tobin's Q and working capital management among selected firms from Tehran Stock Exchange (Gundavelli, 2006). The proposed study gathers the necessary financial information from 219 different firms over the period 2001-2011 and categorizes them based on nine different sectors. There are five independent variables including current ratio, the ratio of current assets to total assets, debt ratio, the ratio of current liabilities to total assets and total cash.

$C R_{i t}(n t)=$ Cash of the firm (industry) $i(n)$ in time $t$,

$C A C L R_{i t}(n t)=$ Current assets to current liabilities of firm (industry) $i(n)$ for time $t$,

$\operatorname{CATAR}_{i t}(n t)=$ Current assets to total assets of firm (industry) $i(n)$ in time $t$,

$C_{L T A R}(n t)=$ Current liabilities to total assets of firm (industry) $i(n)$ in time $t$,

$D R_{i t}(n t)=$ Total debt to total assets of firm (industry) $i(n)$ in time $t$,

$e=$ error term of the model

There are two regression models and two dependent variables as follows,

$T Q_{i t}=$ Tobin's $\mathrm{Q}$ of firm $i$ for time $t$,

$T Q_{n t}=$ Tobin's Q of industry $i$ for time $t$.

Tobin's $\mathrm{Q}$ is calculated as Tobin's $Q=(M V E+B V E) / T A E$ where $M V E$ represents market value of equity, $B V E$ is equal to total liabilities of the firms, which are subject to interest and $T A E$ is equal to total assets of the firm (Chung \& Pruitt, 1994). The proposed model of this paper uses the following two models to verify the hypothesis of this survey,

$$
\begin{aligned}
& T Q_{i t}=\beta 0+\beta 1\left(\operatorname{cr}_{i, t}\right)+\beta 2\left(\operatorname{caclr}_{i, t}\right)+\beta 3\left(\text { catarit }_{i, t}\right)+\beta 4\left(\text { cltar }_{i, t}\right)+\beta 5\left(d_{r i, t}\right)+\varepsilon_{i, t} \\
& T Q_{n t}=\beta 0+\beta 1\left(\text { cr }_{n, t}\right)+\beta 2\left(\text { caclr }_{n, t}\right)+\beta 3\left(\text { catarit }_{n, t}\right)+\beta 4\left(\text { cltar }_{n, t}\right)+\beta 5\left(d_{n, t}\right)+\varepsilon_{n, t}
\end{aligned}
$$

Table 1 demonstrates the summary of some basic statistics on some selected data.

Table 1

\begin{tabular}{|c|c|c|c|c|c|c|c|c|}
\hline \multirow{2}{*}{ Variable } & \multirow{2}{*}{ \# } & \multirow{2}{*}{ Mean } & \multirow{2}{*}{ Standard dev. } & \multirow{2}{*}{ Variance } & \multirow{2}{*}{ Skewness } & \multirow{2}{*}{ Kurtosis } & \multicolumn{2}{|c|}{ Deviation } \\
\hline & & & & & & & Skewness & Kurtosis \\
\hline Current ratio & 1971 & 1.089 & 0.565 & 0.319 & 2.521 & 12.931 & 45.732 & 117.334 \\
\hline Current assets to total assets & 1971 & 0.616 & 0.208 & 0.043 & -0.630 & -0.377 & 11.428 & -3.420 \\
\hline Current liabilities to total assets & 1971 & 0.659 & 0.416 & 0.173 & 5.581 & 53.650 & 101.230 & 486.811 \\
\hline Total debt to total assets & 1971 & 0.760 & 0.421 & 0.177 & 5.541 & 51.899 & 100.500 & 470.917 \\
\hline Cash of the firm & 1971 & 0.068 & 0.077 & 0.006 & 3.977 & 31.052 & 72.144 & 281.755 \\
\hline Tobin's Q & 1971 & 0.925 & 1.174 & 1.377 & 3.772 & 18.488 & 68.418 & 167.754 \\
\hline
\end{tabular}

The summary of some basic statistics 
Since the proposed study of this paper intends to use linear regression technique, we need to make sure about the normality of data. Table 2 summarizes the results of our survey based on three different statistical observations and the results indicate that the data were not normally distributed.

\section{Table 2}

The summary of Kolmogorov-Smirnov, Shapiro-Wilk and Jarque- Bera

\begin{tabular}{lccccccc}
\hline \multicolumn{1}{c}{ Variable } & \multirow{2}{*}{$\#$} & \multicolumn{2}{c}{ Kolmogorov-Smirnov } & \multicolumn{2}{c}{ Shapiro-Wilk } & \multicolumn{2}{c}{ Jarque- Bera } \\
& & Statistic & Error & Statistic & Error & Statistic & Error \\
\hline Current ratio & 1971 & .124 & 0.000 & .829 & 0.000 & 15741.53 & 0.000000 \\
Current assets to total assets & 1971 & .084 & 0.000 & .954 & 0.000 & 141.9983 & 0.000000 \\
Current liabilities to total assets & 1971 & .191 & 0.000 & .616 & 0.000 & 245378.7 & 0.000000 \\
Total debt to total assets & 1971 & .226 & 0.000 & .600 & 0.000 & 230126.2 & 0.000000 \\
Cash of the firm & 1971 & .189 & 0.000 & .692 & 0.000 & 83957.71 & 0.000000 \\
Tobin's Q & 1971 & .219 & 0.000 & .603 & 0.000 & 32585.63 & 0.000000 \\
\hline
\end{tabular}

Table 3 also summarizes the results of different statistics to verify whether we should use pooled or panel method.

Table 3

The summary of

\begin{tabular}{|c|c|c|c|c|c|c|c|c|}
\hline & \multirow{2}{*}{ Group } & \multirow{2}{*}{ Goal } & \multicolumn{3}{|c|}{ Chow } & \multicolumn{3}{|c|}{ Hausman } \\
\hline & & & $\mathrm{F}$ & Sig. & Result & Chi-Square & Sig. & Result \\
\hline \multirow{2}{*}{1} & \multirow{2}{*}{ Total } & Pooled & 18.797216 & 0.0000 & Not equal intercept & 0.000000 & 1.0000 & Random Effects \\
\hline & & Panel & 6.522316 & 0.0000 & Not equal slope & 4.891623 & 0.4292 & Random Effects \\
\hline \multirow{2}{*}{2} & \multirow{2}{*}{ Solid Sugar and sugar } & Pooled & 2.581183 & 0.0117 & Not equal intercept & 0.000000 & 1.0000 & Random Effects \\
\hline & & Panel & 3.640038 & 0.0000 & Not equal slope & 0.000000 & 1.0000 & Random Effects \\
\hline \multirow{2}{*}{3} & \multirow{2}{*}{ Food excluding sugar } & Pooled & 2.523603 & 0.0117 & Not equal intercept & 2.791580 & 0.7321 & Random Effects \\
\hline & & Panel & 1.545395 & 0.0426 & Not equal slope & 2.813692 & 0.7287 & Random Effects \\
\hline \multirow{2}{*}{4} & \multirow{2}{*}{ Plastic and rubber } & Pooled & 0.880886 & 0.5348 & Equal intercept & & & \\
\hline & & Panel & 2.903612 & 0.0009 & Not equal slope & 2.835487 & 0.7253 & Random Effects \\
\hline \multirow{2}{*}{5} & \multirow{2}{*}{ Basic metals } & Pooled & 2.228883 & 0.0266 & Not equal intercept & 7.758015 & 0.1701 & Random Effects \\
\hline & & Panel & 1.320228 & 0.1544 & Equal slope & & & \\
\hline \multirow{2}{*}{6} & \multirow{2}{*}{$\begin{array}{l}\text { Equipment and } \\
\text { machinery }\end{array}$} & Pooled & 2.622964 & 0.0091 & Not equal intercept & 18.104703 & 0.0028 & Fixed Effects \\
\hline & & Panel & 2.107326 & 0.0018 & Not equal slope & 14.172157 & 0.0146 & Fixed Effects \\
\hline \multirow{2}{*}{7} & \multirow{2}{*}{ Part makers } & Pooled & 6.115038 & 0.0000 & Not equal intercept & 0.000000 & 1.0000 & Random Effects \\
\hline & & Panel & 2.638049 & 0.0001 & Not equal slope & 48.393902 & 0.0000 & Fixed Effects \\
\hline \multirow{2}{*}{8} & \multirow{2}{*}{ Non-metal } & Pooled & 1.235182 & 0.2811 & Equal intercept & & & \\
\hline & & Panel & 3.571285 & 0.0000 & Not equal slope & 1.501496 & 0.9129 & \\
\hline \multirow{2}{*}{9} & \multirow{2}{*}{ Cement } & Pooled & 12.294129 & 0.0000 & Not equal intercept & 10.815195 & 0.0552 & Random Effects \\
\hline & & Panel & 3.359057 & 0.0000 & Not equal slope & 21.822508 & 0.0006 & Fixed Effects \\
\hline \multirow{2}{*}{10} & \multirow{2}{*}{ Drug } & Pooled & 10.689500 & 0.0000 & Not equal intercept & 11.557458 & 0.0414 & Random Effects \\
\hline & & Panel & 3.549734 & 0.0000 & Not equal slope & 28.639809 & 0.0000 & Fixed Effects \\
\hline
\end{tabular}

Now, we are able to consider other important relationship among independent components and residuals. Table 4 summarizes the results of F-statistics, Durbin-Watson, etc.

Table 4

The summary of F-statistics, Durbin-Watson and J B

\begin{tabular}{ccccccc}
\hline \multirow{2}{*}{ Model } & \multicolumn{2}{c}{ Linearity test } & \multicolumn{2}{c}{ Durbin-Watson } & \multicolumn{2}{c}{ Residual test } \\
\cline { 2 - 7 } & F & Sig. & Value & Range & J_B statistics & Sig. \\
\hline 1 & 17.61734 & 0.000000 & 1.584184 & $2.5-1.5$ & 138.50 & 0.000000 \\
2 & 6.059623 & 0.000039 & 1.546586 & $2.5-1.5$ & 44.16 & 0.000000 \\
3 & 6.566695 & 0.000009 & 1.519414 & $2.5-1.5$ & 201.116 & 0.000000 \\
4 & 2.567749 & 0.001092 & 1.736060 & $2.5-1.5$ & 2569.144 & 0.000000 \\
5 & 5.356019 & 0.000115 & 1.603270 & $2.5-1.5$ & 9294.388 & 0.000000 \\
6 & 2.962216 & 0.000000 & 1.721660 & $2.5-1.5$ & 13161.45 & 0.000000 \\
7 & 6.430626 & 0.000000 & 1.540982 & $2.5-1.5$ & 994.257 & 0.000000 \\
8 & 2.331074 & 0.044154 & 1.581440 & $2.5-1.5$ & 1676.694 & 0.000000 \\
9 & 5.171825 & 0.000000 & 1.587526 & $2.5-1.5$ & 33.615 & 0.000000 \\
10 & 7.695595 & 0.000000 & 1.504611 & $2.5-1.5$ & 156.3738 & 0.000000 \\
\hline
\end{tabular}


As we can observe from the results of Table 4, all F-value statistics are significant with $\alpha=5 \%$. In addition, all Durbin-Watson values are within acceptable limit, which means there is no autocorrelation among residuals. Finally, we have considered the correlation ratios among independent variables and we may precede the regression analysis.

\section{The results}

In this section, we present details of our investigation on measuring the impact of various factors on Tobin's Q. The results of linear regression model are given in Eq. (3) as follows,

$T Q=1.217+0.114 * C A C L R+0.068 * C A T A R+1.284 * C L T A R-1.218 * D R+1.091 * C R-0.8469 * D U M 1-0$. $7763 * D U M 2$ - 0. $82 * D U M 3$ - 0. $703906620522 * D U M 4$ - 0. $919 * D U M 5$ - 0.828*DUM6 - 0. $81 * D U M 7+1.27 * D U M 8$

In Eq. (4), F-value $=17.61734$, Durbin-Watson $=1.584184$ and Adjusted R-Square $=0.104768$. In addition, all t-student values are statistically significance with $\alpha=5 \%$. Therefore, we can confirm the main hypothesis of this survey and conclude that working capital positively influences Tobin-Q.

\subsection{The effect of working capital on Tobin-Q in Sugar industry}

The first sub-hypothesis of this survey is associated with the effect of working capital on Tobin-Q in Sugar industry, which is summarized in Eq. (5) as follows,

$T Q=0.392+0.349^{*} C A C L R-0.535^{*} C A T A R-0.328 * C L T A R+0.399 * D R+1.044 * C R$

In Eq. (5), F-value $=6.059623$, Durbin-Watson $=1.546586$ and Adjusted R-Square $=0.142687$. In addition, all t-student values are statistically significance with $\alpha=5 \%$. Therefore, we can confirm the first sub-hypothesis of this survey and conclude that working capital positively influences Tobin-Q in sugar industry.

\subsection{The effect of working capital on Tobin-Q in Food industry excluding sugar}

The second sub-hypothesis of this survey is associated with the effect of working capital on Tobin-Q in Food industry excluding sugar, which is summarized in Eq. (6) as follows,

$T Q=0.805+0.232 * C A C L R-0.766^{*} C A T A R+0.472 * C L T A R-0463 * D R+0.810 * C R$

In Eq. (6), F-value $=6.566695$, Durbin-Watson $=1.519414$ and Adjusted R-Square $=0.093768$. In addition, most t-student values are statistically significance with $\alpha=5 \%$. Therefore, we can confirm the second sub-hypothesis of this survey and conclude that working capital positively influences Tobin-Q in food industry.

\subsection{The effect of working capital on Tobin-Q in Rubber and Plastic}

The third sub-hypothesis of this survey is associated with the effect of working capital on Tobin-Q in Rubber and Plastic industry, which is summarized in Eq. (7) as follows,

$T Q=0.805+0.232 * C A C L R-0.766 * C A T A R+0.472 * C L T A R-0463 * D R+0.810 * C R$

In Eq. (7), F-value $=2.567749$, Durbin-Watson $=1.736060$ and Adjusted R-Square $=0.023637$. In addition, most $\mathrm{t}$-student values are statistically significance with $\alpha=5 \%$. Therefore, we can confirm the third sub-hypothesis of this survey and conclude that working capital positively influences Tobin$\mathrm{Q}$ in Rubber and Plastic industry. 


\subsection{The effect of working capital on Tobin-Q in Basic metals}

The fourth sub-hypothesis of this survey is associated with the effect of working capital on Tobin-Q in basic metals industry, which is summarized in Eq. (8) as follows,

$T Q=0.332+0.297 * C A C L R-0.227 * C A T A R+0.823 * C L T A R-0.718 * D R+2.174 * C R$

In Eq. (8), F-value $=5.356019$, Durbin-Watson $=1.603270$ and Adjusted R-Square $=0.088616$. In addition, most $t$-student values are statistically significance with $\alpha=5 \%$. Therefore, we can confirm the fourth sub-hypothesis of this survey and conclude that working capital positively influences Tobin-Q in basic metals industry.

\subsection{The effect of working capital on Tobin- $Q$ in machinery and equipment}

The fifth sub-hypothesis of this survey is associated with the effect of working capital on Tobin-Q in machinery and equipment industry, which is summarized in Eq. (9) as follows,

$T Q=0.663+0.107 * C A C L R-0.349 * C A T A R+0.0657^{*} C L T A R-0.164 * D R+1.047 * C R$

In Eq. (9), F-value $=2.962216$, Durbin-Watson $=1.721660$ and Adjusted R-Square $=0.238213$. In addition, most $t$-student values are statistically significance with $\alpha=5 \%$. Therefore, we can confirm the fifth sub-hypothesis of this survey and conclude that working capital positively influences Tobin$\mathrm{Q}$ in machinery and equipment industry.

\subsection{The effect of working capital on Tobin-Q in Auto industry}

The sixth sub-hypothesis of this survey is associated with the effect of working capital on Tobin-Q in Auto industry, which is summarized in Eq. (10) as follows,

$T Q=0.795+0.055^{*} C A C L R-0.264 * C A T A R+0.284 * C L T A R-0.402 * D R-0.060 * C R$

In Eq. (10), F-value = 6.430626, Durbin-Watson $=1.540982$ and Adjusted R-Square $=0.219523$. In addition, most $\mathrm{t}$-student values are statistically significance with $\alpha=5 \%$. Therefore, we can confirm the sixth sub-hypothesis of this survey and conclude that working capital positively influences Tobin$\mathrm{Q}$ in Auto industry.

\subsection{The effect of working capital on Tobin-Q in Cement industry}

The seventh sub-hypothesis of this survey is associated with the effect of working capital on Tobin-Q in Cement industry, which is summarized in Eq. (11) as follows,

$T Q=0.826-0.567 * C A C L R+5.401 * C A T A R+3.641 * C L T A R-2.450 * D R+2.254 * C R$

In Eq. (11), F-value $=5.171825$, Durbin-Watson $=1.587526$ and Adjusted R-Square $=0.348283$. In addition, most t-student values are statistically significance with $\alpha=5 \%$. Therefore, we can confirm the seventh sub-hypothesis of this survey and conclude that working capital positively influences Tobin-Q in Cement industry.

\subsection{The effect of working capital on Tobin-Q in Drug industry}

The eighth sub-hypothesis of this survey is associated with the effect of working capital on Tobin-Q in Drug industry, which is summarized in Eq. (12) as follows, 
In Eq. (12), F-value $=7.695595$, Durbin-Watson $=1.504611$ and Adjusted R-Square $=0.516213$. None of the t-student values is statistically significance with $\alpha=5 \%$ or even $\alpha=10 \%$. Therefore, we cannot confirm the eighth sub-hypothesis of this survey and conclude that working capital positively influences Tobin-Q in Drug industry.

\section{Conclusion}

In this paper, we have presented an empirical investigation to study the effect Tobin-Q on working capital on selected firms from Tehran Stock Exchange. We have examined the main hypothesis of this survey in all industries as well as individual industries. Table 5 shows details of our findings,

\section{Table 5}

The summary of investigating various hypotheses

\begin{tabular}{|c|c|c|c|c|c|}
\hline Industry & Cash ratio & $\begin{array}{l}\text { Current } \\
\text { ratio }\end{array}$ & $\begin{array}{l}\text { Ratio of current assets to total } \\
\text { assets }\end{array}$ & $\begin{array}{l}\text { Ratio of current liabilities to total } \\
\text { assets }\end{array}$ & Debt ratio \\
\hline Sugar & $\sqrt{ }$ & $\sqrt{ }$ & $\sqrt{ }$ Reverse & $\times$ & $x$ \\
\hline Food excluding sugar & $\sqrt{ }$ & $\sqrt{ }$ & $\sqrt{ }$ Reverse & $\sqrt{ }$ & Reversed \\
\hline Rubber \& Plastic & $x$ & $\sqrt{ }$ & $\times$ & $\times$ & $x$ \\
\hline Basic metals & $\times$ & $\sqrt{ }$ & $x$ & $\sqrt{ }$ & Reversed \\
\hline Machinery \& Equipment & $\sqrt{ }$ & $\times$ & $x$ & $\times$ & $\times$ \\
\hline Auto industry & $\times$ & $\times$ & $\times$ & $\sqrt{ }$ & Reversed \\
\hline Non-metal & $x$ & $\times$ & $x$ & $\times$ & $x$ \\
\hline Cement & $\sqrt{ }$ & $\times$ & $\sqrt{ }$ & $\sqrt{ }$ & Reversed \\
\hline Drug & $\times$ & $\times$ & $\times$ & $\times$ & $x$ \\
\hline Confirmed & 4 & 4 & 3 & 4 & 4 \\
\hline Not-confirmed & 5 & 5 & 6 & 5 & 5 \\
\hline Final result & Confirme & Confirmed & Reject & Confirmed & Confirmed \\
\hline
\end{tabular}

\section{References}

Chung, K. H., \& Pruitt, S. W. (1994). A simple approximation of Tobin's q. Financial management, 23(3).

Deloof, M. (2003). Does working capital management affect profitability of Belgian firms?. Journal of Business Finance \& Accounting, 30(3-4), 573-588.

Eljelly, A. M. (2004). Liquidity-profitability tradeoff: an empirical investigation in an emerging market. International Journal of Commerce and Management, 14(2), 48-61.

Filbeck, G., \& Krueger, T. (2005). Industry related differences in working capital management. MidAmerican Journal of Business, 20(2), 11-18.

García-Teruel, P. J., \& Martínez-Solano, P. (2007). Effects of working capital management on SME profitability. International Journal of Managerial Finance, 3(2), 164-177.

Gardner, M. J., Mills, D. L., \& Pope, R. A. (1986). Working capital policy and operating risk: An empirical analysis. Financial Review, 21(3), 31-31.

Gundavelli, V. (2006). 7 steps to elevating working capital performance. Financial Executive, 22(4), 52.

Padachi, K. (2006). Trends in working capital management and its impact on firms' performance: an analysis of Mauritian small manufacturing firms. International Review of Business Research Papers, 2(2), 45-58.

Samiloglu, F., \& Demirgunes, K. (2008). The effect of working capital management on firm profitability: evidence from Turkey. The International Journal of Applied Economics and Finance, 2(1), 44-50. 